\title{
Landslide hazard mapping of Phewa Lake catchment area, Pokhara, central west Nepal
}

\author{
S.M. Sikrikar ${ }^{1}$, L.N. Rimal ${ }^{1}$, S. Jäger ${ }^{2}$ \\ 'Department of Mines and Geology, Lainchaur, Kathmandu, Nepal \\ ${ }^{2}$ Gundra, Jager and Schroeder Gbr, PO BOX 102462, 69104 Heidelberg, Germany
}

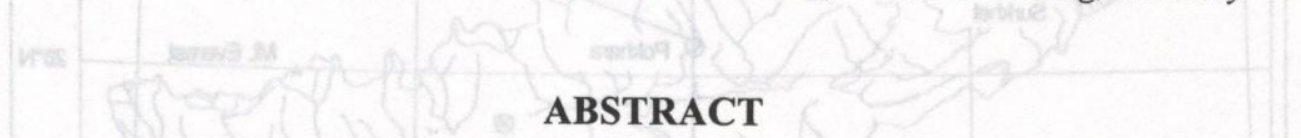

The landslide hazard map of the Phewa Lake catchment area is based on empirical evaluation of the data related to slope instability, obtained through field investigation and various types of geo-scientific maps. The methodology includes making of different types of base maps of various factor that contribute to slope instability of the terrain. Some weighted values are derived for each factor taken into consideration by statistical analysis. According to their significance in slope failure, different numerical values are assigned to each factors. GIS technique is used for integrating all weighted values into final landslide hazard map.

By assessing the total weighted values in the final map, the catchment area is divided into high, medium and low hazard zones according to the chances of occurring landslides at specific area. Most of the existing old and active landslides fall within high hazard zone, which indicate the suitability of this method in preparing landslide hazard map.

\section{INTRODUCTION}

The catchment area of the Phewa Lake (Fig. 1) was chosen because detailed geological mapping and mapping of landslide and erosional features were already carried out. The catchment is located in the central part of Nepal, near the city of Pokhara. Physiographically, it is a part of the Nepalese Middle Mountains, also geologically known as the Lesser Himalaya.

The total area of the catchment covers about $112 \mathrm{~km}^{2}$. The Harpan Khola and Andheri Khola are the main tributaries of the lake. Panchase is the highest mountain peak situated at the western part of the catchment measuring $2509 \mathrm{~m}(8231 \mathrm{ft})$. Naudanda and Sarangkot are other important peaks in the area. The area receives more than $3000 \mathrm{~mm}$ of rainfall a year, most of which is falling during the monsoon period between June and September.

The mountainous terrain in Nepal Himalaya is generally characterised by steep slopes, high relief, highly weathered and densely jointed rocks with unfavorable hydrogeological conditions with respect to slope stability. Continuous deposition of the sediments into the Phewa lake has decreased the lake area in considerable amount in the recent years. The stability conditions of the slopes are further affected by intense human activities and improper land use practices.

Before planning of any development activities in this region the existing stability conditions of the terrain should be assessed so that the development activities may be implemented with minimum environmental degradation. By systematic assessment of the environmental degradation suitable preventive measures and restoration works can be planned. For this purpose some of the steps that could be taken for better management of the environmental geological aspects is the preparation of landslide hazard map. The Landslide Hazard Mapping serves as a good example for the value of geoscientific studies in a rapidly growing urban environment. 


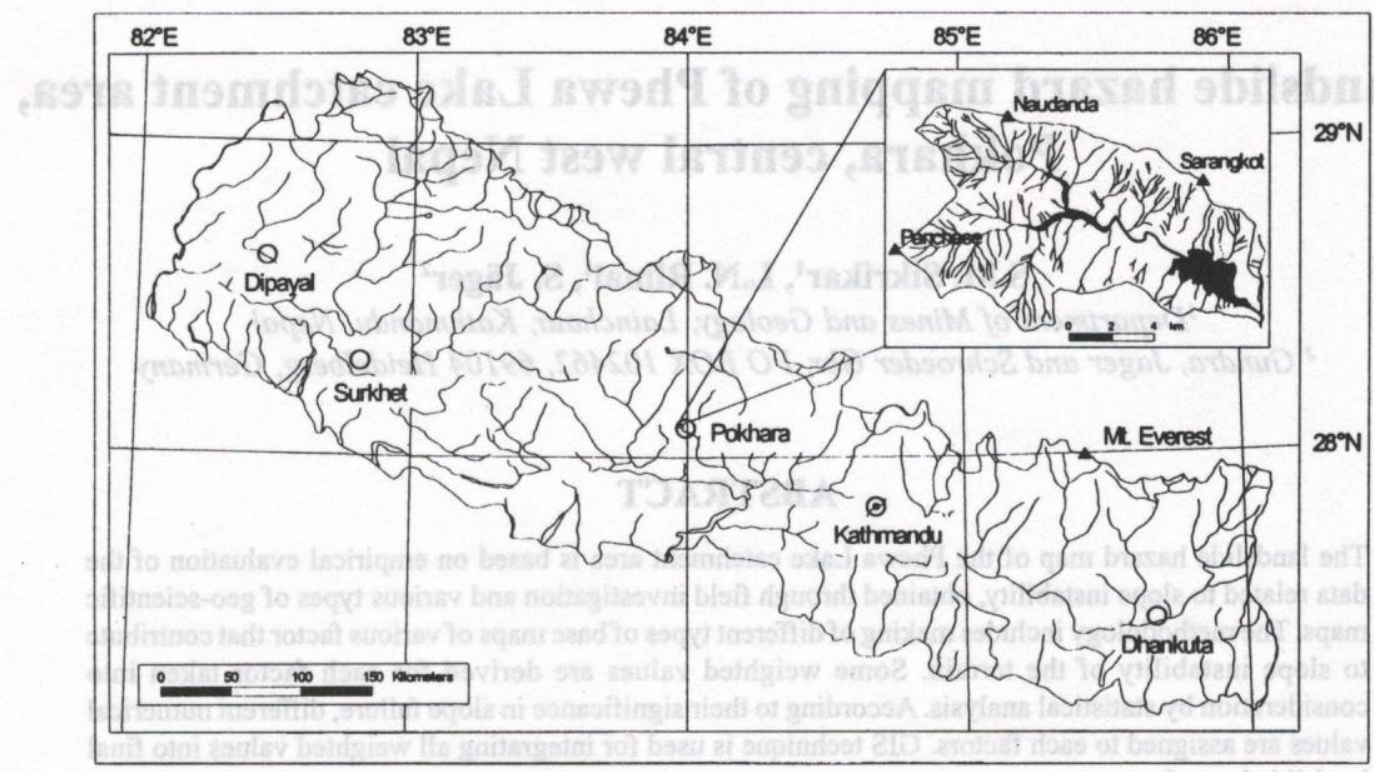

Fig. 1: Location map of the study area.

\section{METHODOLOGY}

Various methods of hazard assessment have been proposed and demonstrated in Nepal and other Himalayan areas (e.g. Kienholz et al., 1983). Upreti and Dhital (1996) summarise various examples of landslide hazard mapping throughout Nepal. This paper presents the efforts made by the Department of Mines and Geology to develop a methodology directed towards institutionalised hazard assessment for the application by planning authorities. With the advent of geographic information systems (GIS), their use for landslide hazard assessment has increased constantly (Carrara et al., 1991; Van Westen, 1994; Jager, 1997). In the present study, GIS is used for analysis, modeling and cartographic purpose.

Landslides are the result of various causative factors affecting slope instability at a specific place. The first step in our study was to map individual landslides in the field and subsequently digitise them for the purpose of a landslide inventory. Subsequently, the presumed causative factors were either mapped in the field or gathered from other data sources, and transferred to GIS data layers.
Statistical analysis was performed on each data layer to calculate the aerial extent to which each layer (factor) is covered by landslides, i.e. the relative frequencies of landslide occurrence. This approach follows closely the methods presented by Aniya (1985) and Brabb (1984) and can be described as a bivariate model. The degree to which each factor contributes to specific landslides differs significantly. As a measure of this degree, the calculated aerial extent by which each particular unit is covered by landslides is used. In the present study this is called the LFvalue (Landslide Frequency). The GIS is then utilised to derive new spatial units by intersecting the base maps (i.e. factor maps). These newly created units carry the LF-values of each particular factor. As a measure of instability the LF-values are summed up. Hazard classes are then derived by classifying the LF sums. For the study, a simple classification was aspired in order to make them easily legible by non-geologists. In the study the acquired data were grouped in natural and man-made factors (Table 1).

Due to constraints in the software applied, only factors of areal nature could be utilised for the hazard assessment. Linear and point type 
Table 1: Natural and man-made factors considered in the study.

causative factors are not considered in the present study.

\section{Data acquisition and analysis}

The data required for hazard mapping were obtained from topographic maps, aerial photographs, landuse maps at 1:50,000 (Zonneveld et al., 1986) together with extensive field survey of the area. The effects of causative factors on slope instability were mapped on topographical maps of 1:25,000 scale enlarged from 1:50,000 and aerial photographs of 1:20,00 scale. Geological data were obtained from detailed field mapping (Table 2). The rock units were separated on the basis of their lithological appearance. The rocks of the catchment are comprised mostly of metasediments of the Lesser Himalaya.

The rocks exposed in the area belong to the Kuncha Formation (Stöcklin et al., 1980). The Kuncha Formation is the oldest rock unit of Precambrian age. The formation comprises mostly of gritty phyllites, greenish gray phyllites, talcosic phyllites and gray banded thickly bedded gray quartzites. The greenish gray banded quartzites and phyllites occur in the upper part of the formation. Layers of basic rocks, mostly of amphibolites are found interbedded in Kuncha Formation at a number of places. The thickness of these intrusive rocks varies from a few metres to tens of metres near the upper reaches of the Harpan Khola. The Kuncha Formation is overlain by white massive quartzite equivalent to the Fagfog Quartzite (Stocklin et al., 1980). The characteristic features of this formation are abundant ripple marks and intercalating green phyllites. The rocks of the formation are well exposed in the western part of the catchment.

The Tallakot Formation and the Ghachok Formation (Yamanaka et al., 1982) are two major debris flow deposits found within the catchment area. These formations comprise of gravel to boulder sized rock fragments mainly derived from the Higher Himalaya. They are well cemented by a calcareous matrix. Different types of soil units are also identified and differentiated on the basis of their origin and composition.

The structural data on bedding planes, joints, faults, foliations, cleavages, etc. have been recorded as far as

Table 2: Data types and sources.

\begin{tabular}{|l|l|l|l|}
\hline Data layer & Data source & Scale & Year \\
\hline Geology/Lithology & Field Mapping & $1: 25000$ & mapped in 1995 \\
\hline Landuse & LRMP, Sheets No. 62P/15 \& 62P/16 & $1: 50000$ & $\begin{array}{l}\text { based on aerial photographs from 1978/79, } \\
\text { updated by field mapping 1995 }\end{array}$ \\
\hline Slope & $\begin{array}{l}\text { Topographic Maps, Sheets No. } \\
62 \mathrm{P} / 15 \text { \& 62P/16 }\end{array}$ & $1: 50000$ & $\begin{array}{l}\text { manually measured from topographic maps } \\
1: 50000\end{array}$ \\
\hline Soil & Field Mapping & $1: 25000$ & mapped in 1995 \\
\hline Landslides & Field Mapping & $1: 25000$ & mapped in 1995 \\
\hline
\end{tabular}




\section{S.M. Sikrikar et al.}

possible throughout the study area. The hydrogeological conditions of different slopes were assessed in the field by direct observation on springs, seepage, etc. Further details about the engineering geological framework of the area was taken from Koirala et al. (1998).

Soil units were mapped according to their type of formation and thus classified as residual, colluvial, alluvial and fan deposits. The slope map of this catchment area was prepared manually, utilising topographic base maps at a scale of 1:50000. The grid squares of the maps were subdivided in four squares, measuring about $0.5 \mathrm{~cm}$ by $0.5 \mathrm{~cm}$. Slope inclination is then determined by dividing the elevation range by the squares length. The calculated slope values were subsequently classified. This method has several drawbacks, including its time-consuming nature and the lack of the possibility to redefine the slope classes. In further studies, it is thus intended to utilise digital elevation models and derive slope inclination values. Table 2 gives the information about the acquired data.

The landuse map of Zonneveld et al. (1986) was used as the base map for producing the landuse map for this study. After a careful evaluation of the map together with recent aerial photograph, interpretation and field check, a regrouping of each landuse map unit was carried out in terms of anticipated slope stability. The regrouping was based on the type and density of the vegetation cover, nature of cultivation, and landuse management system.

Data analysis was carried out utilising GIS and standard spreadsheet software. The basic units were the polygons resulting from the intersection of the basic factor maps. The intersecting procedure allows for the determination of each factor at any place through a common key (Table 3). A total of 1978 units were formed as a result of the intersection. Based on these units various statistical values could be derived. The most important was the determination of percentages of the aerial coverage of each factor in comparison with the portion of which it is covered by landslides. Results of this calculation are presented in Table 4.

Table 3: Example of basic map units.

\begin{tabular}{|c|c|c|c|c|c|}
\hline Key & Landslide & Geology & Soil & Landuse & Slope \\
\hline 101 & yes & phyllite & talus & barren & $20-30^{\circ}$ \\
\hline 102 & no & quartzite & residual & dense forest & $0-10^{\circ}$ \\
\hline
\end{tabular}

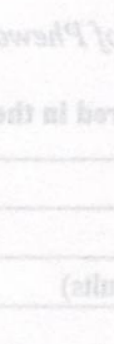

7

를

$\begin{array}{lllll}\pi & 0 & 0 & 0 & -\end{array}$

응

๘

ते लें लं

$=$ i ?

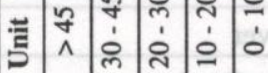

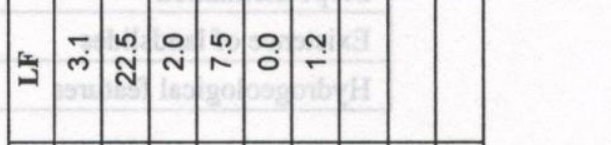

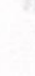

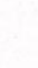

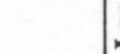

苨

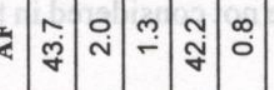
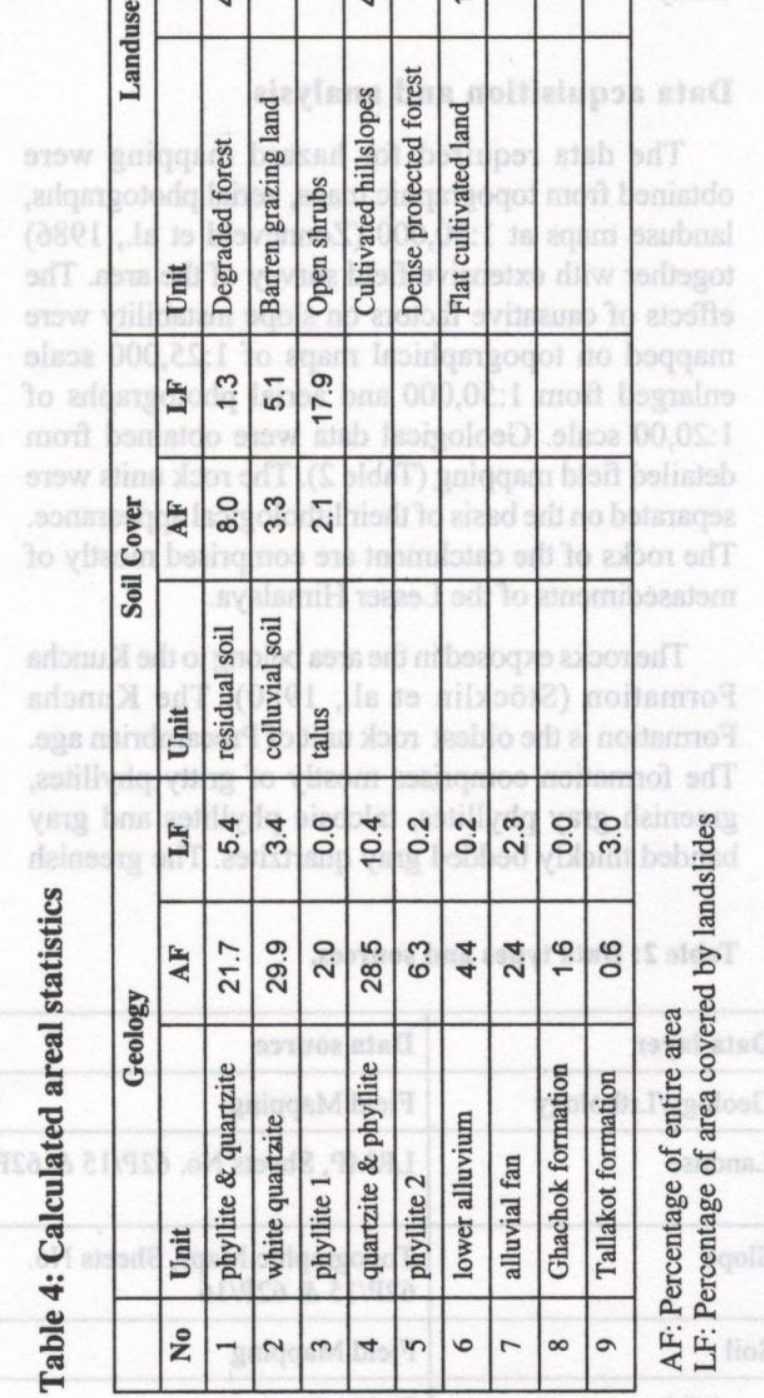

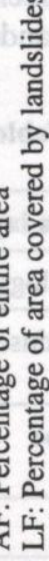


Landslide hazard mapping of Phewa Lake catchment area, Pokhara, central west Nepal

\section{Map Compilation}

To prepare hazard map (Fig. 2), a weighting value each unit was rated with the LF-value representing the percentage by which each particular unit is affected by landslides. It is a measure that allows to compare the relative

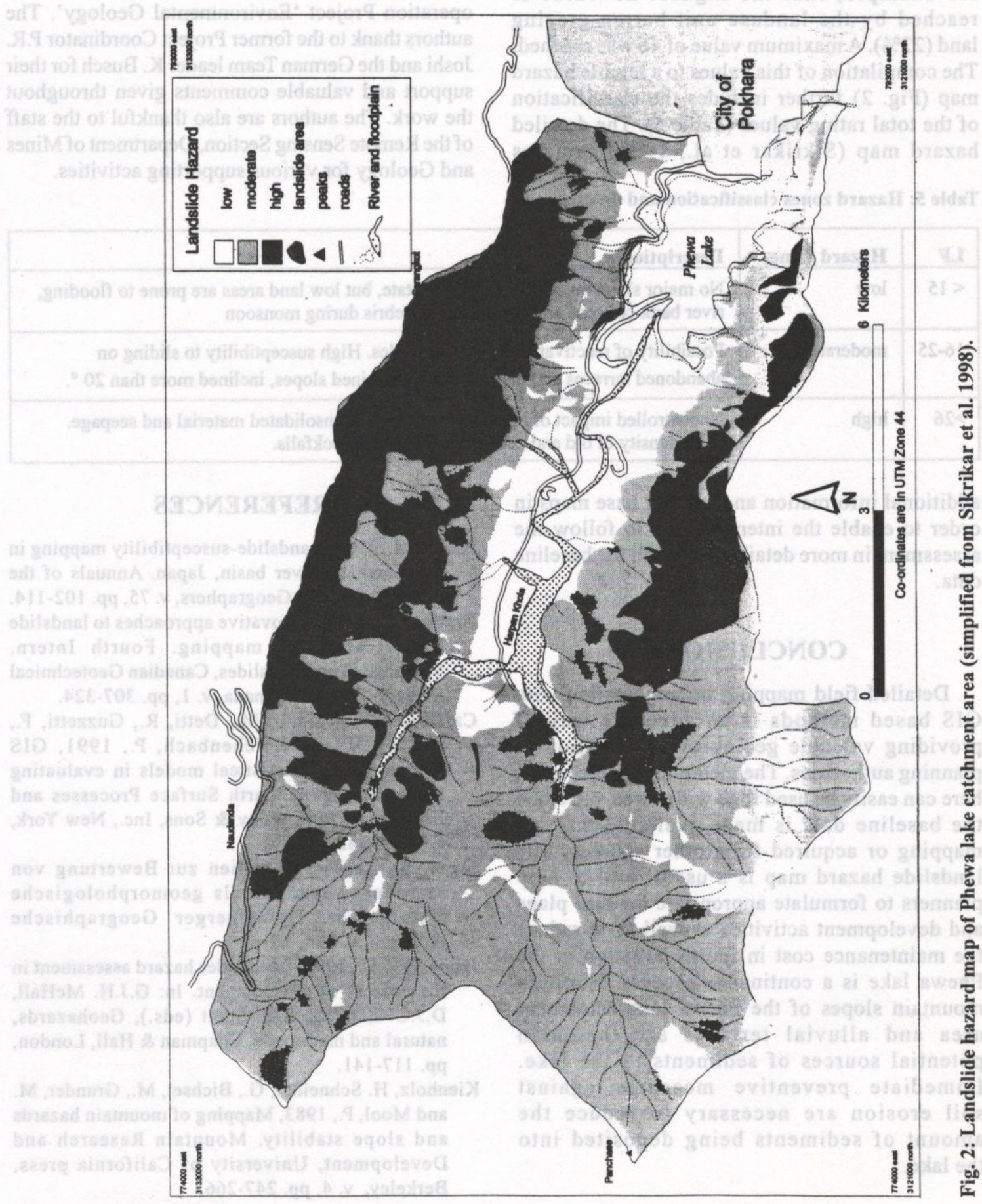


occurrence of landslides within each factor map as well as it allows to compare particular units between different factors. It can be seen, for example, that the highest LF-value is reached by the landuse unit barren grazing land $(22 \%)$. A maximum value of 46 was reached. The compilation of this values to a legible hazard map (Fig. 2) further includes the classification of the total rating values (Table 5). The detailed hazard map (Sikrikar et al., 1998) contains

Table 5: Hazard zones classification and description.

\section{ACKNOWLEDGMENTS}

The present study was carried out within the framework of the Nepal-German Technical Cooperation Project 'Environmental Geology'. The authors thank to the former Project Coordinator P.R. Joshi and the German Team leader K. Busch for their support and valuable comments given throughout the work. The authors are also thankful to the staff of the Remote Sensing Section, Department of Mines and Geology for various supporting activities.

\begin{tabular}{|l|l|l|}
\hline LF & Hazard Zone & Description \\
\hline$<15$ & low & $\begin{array}{l}\text { No major slope instability at present state, but low land areas are prone to flooding, } \\
\text { river bank collapse and deposition of debris during monsoon }\end{array}$ \\
\hline $16-25$ & moderate & $\begin{array}{l}\text { Possibility of reactivation of old landslides. High susceptibility to sliding on } \\
\text { abandoned terraces and on cultivated undrained slopes, inclined more than } 20^{\circ} .\end{array}$ \\
\hline$>26$ & high & $\begin{array}{l}\text { Uncontrolled impact of human activity on unconsolidated material and seepage. } \\
\text { High density of old and active landslides and rockfalls. }\end{array}$ \\
\hline
\end{tabular}

additional information and smaller base maps in order to enable the intended user to follow the assessment in more detail and consult the baseline data.

\section{CONCLUSIONS}

Detailed field mapping in combination with GIS based methods is an adequate way of providing valuable geological information to planning authorities. The methodology presented here can easily be used for a wider area, provided the baseline data is made available through mapping or acquired from other sources. The landslide hazard map is a useful tool to help planners to formulate appropriate landuse plans and development activities as well as to reduce the maintenance cost in future. Siltation in the Phewa lake is a continuous process. Northern mountain slopes of the Phewa lake catchment area and alluvial terraces are the main potential sources of sediments to the lake. Immediate preventive measures against soil erosion are necessary to reduce the amount of sediments being deposited into the lake.

\section{REFERENCES}

Aniya, M., 1985, Landslide-susceptibility mapping in the Amahata River basin, Japan. Annuals of the Assoc. American Geographers, v. 75, pp. 102-114.

Brabb, E.E., 1984, Innovative approaches to landslide hazard and risk mapping. Fourth Intern. Symposium on Landslides, Canadian Geotechnical Society, Toronto, Canada, v. 1, pp. 307-324.

Carrara, A., Cardinali, M., Detti, R., Guzzetti, F., Pasqui, V. and Reichenbach, P., 1991, GIS techniques and statistical models in evaluating landslide hazard. Earth Surface Processes and Landforms. John Wiley \& Sons, Inc., New York, v. 16 , pp. $427-445$.

Jäger, S., 1997, Fallstudien zur Bewertung von Massenbewegungen als geomorphologische Naturgefahr. Heidelberger Geographische Arbeiten, v. 108, 151p.

Jones, D.K.C., 1992, Landslides hazard assessment in the context of development. In: G.J.H. McHall, D.J.C. Laming, S.C. Scott (eds.), Geohazards, natural and man-made, Chapman \& Hall, London, pp. 117-141.

Kienholz, H. Schneider, G., Bichsel, M., Grunder, M. and Mool, P., 1983, Mapping of mountain hazards and slope stability. Mountain Research and Development, University of California press, Berkeley, v. 4, pp. 247-266. 
Koirala, A., Rimal, L.N., Shikrikar, S.M., Pradhananga, U.B., and Pradhan, P.M., 1998, Engineering and environmental geological map of the Pokhara valley 1:50000. Department of Mines and Geology, Kathmandu, Nepal.

Sikrikar, S.M., Rimal, L.N., Jäger, S. and Kerntke, M., 1998, Landslide hazard zonation map of Phewa Lake catchment area, Pokhara, Nepal, 1:50,000. Unpublished draft report, Department of Mines and Geology, Kathmandu, Nepal.

Stöcklin, J. and Bhattarai, K.D., 1980, Geology of the Kathmandu area and central Mahabharat Range, Nepal Himalaya. HMG/UNDP Mineral Exploration Project, Technical Report, 86 p.
Upreti, B.N. and Dhital, M.R., 1996, Landslide studies and management in Nepal. ICIMOD, Kathmandu, $87 \mathrm{p}$.

Yamanaka, H., Yoshida, H. and Arita, K., 1982, Terrace landforms and quaternary deposits around Pokhara valley, central Nepal. Jour. Nepal Geol. Soc., v. 2(Special Issue), pp.113-142,

Zonneveld, J.M., Nield, R., Amatya, D.B., Tamrakar, R.M., Subba, K.J., Tiwari., K.N., Adhikari, S. and Aryal, R., 1986, Land utilisation report. Land Resources Mapping Project (LRMP), Department of Survey, HMG/N - CIDA, Canada, 114 p. 